\title{
AL-MUHASSINĀT AL-BADI'IYYAH PADA AYAT-AYAT HUKUM TENTANG BERJUANG DI JALAN ALLAH
}

\author{
Ardiansyah \\ Fakultas Syari'ah dan Ekonomi Islam IAIN Pontianak \\ Email: ardiansera@gmail.com
}

\begin{abstract}
Language characteristic of law is independent, unemotional, and plain in order to avoid ambiguity. Al-Quran with the perfection and miracle of its language make it different from other law sources. This writing addresses the language style of Quranic verses discussing law: the duty to do jihad for the sake of Allah. The verses will be identified using Badi' study byelaborating not only their beautiful meaning (al-muhassināt alma'nawiyah) but their beautiful lafadz (al-muhassināt al-lafdziyah) as well. There are nine muhassināt found in this study. These beauties include meaning (al-muhassināt alma'nawiyah) and lafadz (al-muhassinat al-lafdziyah). Al-Muhassināt al-Ma'nawiyah found in these verses consists of four kinds: Tibaq, Tauriyah, Jam and Taqsim, while alMuhassināt al-Lafdziyah includes two softs of beauties, they are Jinas and Radd al-A'jz ala al-Sadr. These findings prove that the verses do not address jihad emotionally but discuss it beautifully and calmly.
\end{abstract}

Keywords: Ilmu bad̄̄', al-muhassināt al-ma'nawiyah, al-muhassināt al-lafdziyah, verses law.

\begin{abstract}
Abstrak
Karakter bahasa yang digunakan dalam hukum adalah bebas emosi, tanpa perasaan, datar dan kering untuk menghindari dwi makna atau makna ganda. Al-Quran dengan kesempurnaan dan kemukjizatan bahasanya menggunakan gaya bahasa yang berbeda dari gaya bahasa yang digunakan sumber-sumber hukum lainnya. Tulisan ini membahas gaya bahasa yang terdapat pada ayat-ayat hukum yaitu ayat-ayat tentang kewajiban berjihad di jalan Allah. Ayat-ayat tersebut akan dibedah dengan menggunakan ilmu Badi' dengan cara mencari keindahan-keindahan baik pada aspek makna (al-muhassinät al-ma'nawiyah) maupun keindahan-keindahan yang terdapat pada aspek lafadz (al-muhassināt allafdziyah). Hasilnya, penulis menemukan 9 (sembilan) muhassināt. Keindahan-keindahan tersebut tidak hanya pada makna (al-muhassināt al-ma'nawiyah) akan tetapi juga terdapat pada lafadz (al-muhassināt al-lafdziyah). Al-Muhassināt al-Ma'nawiyah dalam ayat-ayat ini ditemukan 4 (empat) jenis, yaitu Țibāq, Tauriyah, Jam' dan Taqsimm. Sedangkan dalam al-Muhassināt al-Lafdziyah ditemukan dua jenis keindahan, yaitu Jinās dan Radd al-A'jz 'ala al-Șadr. Hal ini membuktikan bahwa ayat ini tidak berbicara tentang hukum berjihad dengan penuh emosi akan tetapi disusun dengan nada yang indah dan dengan tensi yang diredam.
\end{abstract}

Kata Kunci: Ilmu bad̄̄, al-muhassināt al-ma'nawiyah, al-muhassināt al-lafdziyah, ayatayat hukum. 


\section{Pendahuluan}

Kesempurnaan al-Quran sebagai kitab yang paling mulia di muka bumi tercermin pada tema-tema yang dikandungnya baik berupa pola hubungan antara manusia dengan Tuhan (hablu min Allah) ataupun hubungan antar manusia (hablu min an-Nās). Kedua pola yang berasal dari al-Quran ini dibaca, dipahami, dan dilaksanakan oleh umat muslim sebagai wujud dari ketaatannya kepada Tuhan.

Ketaatan umat muslim kepada Tuhannya, menempatkan al-Quran sebagai kitab huda (petunjuk) kehidupan di hati pemeluknya. Penempatan ini memposisikan al-Quran sebagai rujukan hukum bagi umat muslim yang mengatur kedua pola tersebut. Bagi seorang muslim, meyakini bahwa hukum Allah yang dikabarkan melalui al-Quran adalah hukum yang terbaik merupakan hal yang tidak bisa ditawar. Hal ini didasari oleh firman Allah SWT:

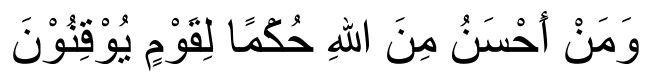

Artinya:

dan (hukum) siapakah yang lebih baik daripada (hukum) Allah bagi orang-orang yang yakin? ${ }^{1}$

Predikat kitab hukum terbaik yang disandang oleh al-Quran tidak mengurangi posisinya sebagai kitab yang terbaik dalam dimensi yang lain. Diantaranya adalah ia juga disebut dengan kitab sastra terbesar ${ }^{2}$. Hal ini dibuktikan dengan dengan keteraturan nada, pemilihan diksi, keindahan makna, kalimat yang spesifik dan berbagai kelebihan lainnya yang dimiliki al-Quran sebagaimana yang dikatakan oleh Sayyid Muhammad al-Maliki bahwa kesempurnaan al-Quran terjalin dalam ayat-ayat yang saling menguatkan, kalimatnya yang spesifik, balagahnya tidak mampu terjangkau oleh akal, kefasihannya di atas semua yang diungkapkan manusia, lafadznya adalah pilihan dan sesuai dengan setiap keadaan, serta sifat-sifat lain yang menunjukkan kesempurnaan al-Quran. ${ }^{3}$

\footnotetext{
${ }^{1}$ Q.S. al-Māidah (5): 50.

${ }^{2}$ Nur Kholis Setiawan, al-Quran Kitab Sastra Terbesar (Yogyakarta: Elsaq Press, 2006)

3 Sayyid Muhammad al-Maliki, Keistimewaan-keistimewaan al-Quran, terj. Nur Fauzin, (Yogyakarta: Mitra Pustaka, t.t), 14-15.
} 
Muhammad Ali aș-Șabūni mempunyai pandangan yang tidak jauh berbeda. Walaupun ia berpendapat bahwa al-Quran bukan merupakan karya sastra, syair, ataupun prosa akan tetapi al-Quran mempunyai uslūb (gaya bahasa) yang sangat baik dan indah, mengagumkan orang-orang Arab karena keserasian, keindahan, dam keharmonisan susunannya. ${ }^{4}$

Sebagai kitab yang menjadi sumber hukum dan di sisi lain sebagai kitab sastra yang memiliki unsur muhassināt (keindahan) tentu bukan perkara yang mudah. Karakter bahasa hukum yang spesifik dan karakter bahasa sastra yang bernada, tidak mudah untuk disandingkan. Apalagi ayat-ayat yang berkenaan dengan hukum perang (jihād) yang memiliki karakter yang tegas dan berwibawa.

Beberapa uraian di atas dapat dikatakan bahwa al-Quran memiliki keistimewaan dari berbagai sudut pandang, dan ini menjadi daya tarik untuk menjadikan al-Quran sebagai kajian tidak pernah putus sepanjang zaman, baik menggunakan pisau ilmu-ilmu modern maupun ilmu-ilmu klasik. Dalam hal ini penulis akan membedah al-Quran menggunakan al-Muhasssināt al-Bad’̀'iyah yang merupakan bagian dari keilmuan balagah yang mengkaji keindahan-keindahan pada teks.

Berdasarkan latar belakang yang telah diuraikan di atas, penulis dapat membuat rumusan masalah yang akan menjadi fokus dan dibahas dalam tulisan ini, yaitu:

1. Apakah dalam ayat-ayat hukum yaitu ayat-ayat kewajiban berjihad di jalan Allah terdapat keindahan-keindahan (al-muhasssināt al-bad’’'iyah), baik secara makna (almuhasssināt al-ma'nawiyah) ataupun secara lafadz (al-muhasssināt al-lafdziyah)

2. Apa saja al-muhasssināt al-bad̄̄'iyah yang terdapat dalam ayat-ayat kewajiban berjihad di jalan Allah?

Tulisan ini akan mengambil objeknya pada surat al-Baqarah ayat 190-195 karena ayat-ayat tersebut berisikan perintah tentang kewajiban berjihad di jalan Allah. Pengklasifikasian ayat-ayat tentang kewajiban berjihad di jalan Allah ini berdasarkan pengklasifikasian oleh M. Ali as-Shabuni dalam kitab Rawāi'ul Bayān Tafsīr Ayatil Ahkām Minal Quran Juz 1 yang sering digunakan oleh santri-santri di Pondok Pesantren.

\footnotetext{
${ }^{4}$ Muhammad Ali aș-Șabūni, Studi Ilmu al-Quran. Terj., (Bandung: Pustaka Setia, 1998), 143.
} 


\section{Bahasa dan Sastra dalam Bingkai Hukum}

Bahasa secara umum merupakan alat komunikasi utama bagi manusia,baik berupa komunikasi lisan,tulisan maupun secara simbolik. Tidak bisa dipungkiri bahwa hukum juga menggunakan ketiga fungsi di atas sebagai alat komunikasi utamanya. Hal ini terjadi karena hukum melibatkan manusia.

Dalam kacamata yang lebih khusus lagi, Bahasa Arab mempunyai posisi yang strategis dalam hukum Islam. Bahasa Arab merupakan bahasa utama dalam Islam,bukan hanya karena Islam lahir di tanah Arab, akan tetapi Bahasa Arab merupakan bahasa yang digunakan oleh umat muslim sebagai dua sumber hukum utama Islam yaitu al-Quran dan as-Sunnah.

Terpilihnya Bahasa Arab sebagai bahasa al-Quran, bukan kebetulan, karena bahasa Arab memiliki sistem yang unik dan unggul dari bahasa-bahasa lain. Komplektisitas bahasa Arab ini menjadi al-Quran 'dipandang Tuhan' sebagai bahasa yang layak untuk menjadi alat komunikasi atau bahasa pembawa wahyu. Komplektisitas bahasa Arab ini terbukti dari banyaknya informasi/makna yang dibawa oleh sebuah kalimah (kata). Sebagai contoh, berikut perbandingan informasi/makna yang dibawa oleh sebuah kata kerja antara bahasa Arab, Inggris, dan Indonesia:

\begin{tabular}{|c|c|c|c|}
\hline \multirow{2}{*}{ Aspek/Bahasa } & B.Arab & Bahasa Inggris & Bahasa Indonesia \\
\cline { 2 - 4 } & yazhabu & Go & pergi \\
\hline Perbuatan & $\sqrt{ }$ & $\sqrt{ }$ & $\sqrt{ }$ \\
\hline Waktu Kejadian & $\sqrt{ }$ & $\sqrt{ }$ & $\mathrm{X}$ \\
\hline Jumlah Pelaku & $\sqrt{ }$ & $\mathrm{X}$ & $\mathrm{X}$ \\
\hline Jenis Kelamin & $\sqrt{ }$ & & \\
\hline
\end{tabular}

Tabel di atas, menjelaskan bahwa pertama, fi'il (kata kerja) yazhabu 'pergi' memuat informasi perbuatan 'pergerakan seseorang dari suatu tempat ke tempat yang lain'. Informasi ini juga dimiliki oleh verb (kata kerja) bahasa Inggris ' $g o$ ' (pergi) dan kata kerja 'pergi' dalam bahasa Indonesia. Kedua, pada informasi waktu kejadian, fi'il yazhabu 
adalah fi'il muḍāri' yang menunjukkan masa sekarang dalam artian fi'il yazhabu bias diterjemahkan sedang pergi. Bahasa Inggris juga memiliki informasi waktu kejadian, karena bahasa Inggris memiliki sistem pembagian waktu pada kata kerja. Verb 'go' tergolong dalam kata kerja simple present tense yang merupakan bentuk waktu yang digunakan untuk menyatakan suatu perbuatan atau kegiatan yang berlansung atau terjadi pada waktu sekarang dalam bentuk sederhana, atau kegiatan yang dilakukan berulangulang, atau kebiasaan sehari-hari atau peristiwa yang tak ada kaitannya dengan waktu. ${ }^{5}$ Jika bahasa Arab dan Inggris memuat informasi waktu, maka kata kerja 'pergi' dalam bahasa Indonesia tidak memiliki informasi waktu.

Pada informasi jumlah pelaku, fi'il yazhabu juga sudah memberikan informasi bahwa jumlah pelaku yang 'pergi' adalah satu orang. Kata yazhabu merupakan sigah 'bentuk' dari fi'il yang berafiliasi dari ḍamìr 'kata ganti' huwa 'dia laki-laki tunggal'. Ini berarti fi' 'il yazhabu berarti 'dia (tunggal) sedang pergi'. Informasi jumlah pelaku ini hanya dimiliki oleh bahasa Arab,sedangkan bahasa Inggris dan Indonesia tidak memuat informasi ini.

Seperti informasi pada jumlah pelaku, bahasa Arab memberikan kejelasan informasi tentang jenis kelamin pada fi'il (kata kerja). Kata kerja yazhabu memberikan informasi bahwa yang pergi adalah seorang laki-laki. Informasi ini didapakan dari sigah yazhabu yang memuat ḍamir huwa yang berkelamin laki-laki. Informasi ini juga tidak ditemukan dalam bahasa Inggris dan bahasa Indonesia.

Komplektisitas sistem bahasa merupakan hal yang mutlak diperlukan bagi bahasa yang membawa sumber hukum, terutama hukum Agama yang pemeluknya tidak mengenal batas negara, suku, kekayaan, jabatan atau lainnya. Luasnya informasi yang dibawa oleh sistem bahasa memberi pengaruh yang luas bagi dunia penafsiran dan pengambilan hukum. Semakin tidak komplek suatu bahasa, maka semakin berpotensi menjadi bahasa yang ambigu atau mempunyai multi makna. Dengan kata lain, bahasa yang tidak komplek akan membawa multi tafsir yang lebih banyak lagi.

Hal ini, tidak berkesuaian dengan karakter bahasa hukum yang mengedepankan mono semantik demi meminimalisir dwi makna. Bahasa hukum yang baku, dalam arti

\footnotetext{
${ }^{5}$ Rudy Hariyono dan Andrew MC. Carthy, ABD Plus English Grammar, (Surabaya: Gitamedia Press, 2008), 407.
} 
harus sesuai dengan kaidah-kaidah bahasa, lugas berarti lansung ke pokok permasalahan, dan mono semantik yang berarti mempunyai kesatuan makna sehingga kalimat tidak ambigu dan tidak multi tafsir.

Oleh karena itu, Bahasa Arab hadir dengan keagungan dan kesempurnaanya yang mengungguli bahasa-bahasa lain di dunia, baik dilihat dari sudut pandang banyaknya pembendaharaan mufradātnya (kosakata) maupun sistem kebahasaannya (gramatikanya).

\section{Balaghah, Sastra dan al-Quran}

Balagah secara bahasa berarti al-wușūlu 'sampai'. Yang dimaksud dengan sampai ialah sampainya pesan yang disampaikan oleh penutur kepada lawan tuturnya. Ilmu Balagah erat kaitannya dengan al-Quran sebagaimana yang didefinisikan oleh Majdi بأصول تعرف بها دقائق اللغة العربية و أسرارها و تتكثف به وجوه الإعجاز في نظر Wahbah dengan 6

Ilmu Balagah merupakan salah satu dari ilmu-ilmu yang lahir dari al-Quran. Dalam keimuan linguistik, Balagah mempunyai posisi yang sangat penting, sering juga disebut dengan ilmu retorika. Ilmu Balagah sudah dikenal oleh bangsa Arab bahkan sebelum menjadi sebuah disiplin ilmu. Dalam perkembangannya, Balagah terus berkembang dan semakin matang seiring turunnya al-Quran sebagai ktab yang memiliki banyak keindahan. 7

Selain dikenal sebagai ilmu retorika, Balagah juga dekenal sebagai ilmu uslüb, yang mungkin bisa disepadankan dengan ilmu stilistika yaitu ilmu tentang gaya bahasa. Balagah mempunyai 3 bidang, yaiut pertama, Ilmu al-Ma'āni, Kedua, Ilmu al-Bayān, Ketiga Ilmu al-Badī’.

Ilmu al-Ma'āni merupakan ilmu yang mengajarkan tentang bagaimana cara menyusun kalimat dengan benar serta sesuai dengan situasi dan kondisi (muqtaḍa $a l-h \bar{a} l)^{8}$

\footnotetext{
${ }^{6}$ Majdi Wahbah dan Kamil Muhandits, Mu'jam al-MuȘtalhāt al-'Arabiyyah fĩ al-Lugati wa al'Alām, (Beirut: Maktabah Lubnan, 1984), 79.

${ }^{7}$ Mardjoko Idris, Ilmu Balghah:Kajian Uslub Jinas dan Iqtibas, (Yogyakarta: Teras, 2007), 3-4.

${ }^{8}$ muqta da al-hāl (sesuai denga situasi dan kondisi) merupakan hal-hal yang perlau mendapatkan perhatian dari penutur (al-mutakallim) agar pembicaraanyya dapat sesuai dengan tuntutan keadaan (mutābaqah li muqtaḍa al-hāl).
} 
Salah satu orang yang membukukan tentang Ilmu al-Ma'āni adalah al-Jāahidz melaui bukunya yang berjudul I'jāz al-Quran.

Ilmu Bayān merupakan ilmu yang mengajarkan bagaimana dapat menyampaikan suatu pesan dengan berbagai macam gaya bahasa, sehingga perkataan yang disampaikan enak didengar dan dibaca. Abu Ubaidah salah satu dari murid Khalil sebagai orang yang pertama membukuku ilmu ini dalam bukunya Majāzu al-Quran. Sedangkan ilmu Badī merupakan yang mengajarakan bagaimana dapat menghias serta memperindah kalimat, baik dari sisi lafadz maupun makna.

Al-Quran mempunyai pengaruh yang kuat terhadap al-Quran, sebagaimana yang dikatakan oleh Theodor Noldoke-seorang orientalis yang menekuni bahasa Arab- dalam bukunya Geschichte des Qorans (Sejarah al-Quran) bahwa al-Quran memiliki pola penulisan yang mirip dengan syair (puisi) Arab. Sehingga kaum Arab banyak yang melacak ayat-ayat al-Quran dan hasilnya kaum Arab menilai bahwa al-Quran memiliki banyak keunggulan dari puisi-puisi mereka.

Bahasa al-Quran mempunyai pengaruh yang sangat kuat bagi sastra Arab ${ }^{9}$, diantaranya:

1. Meskipun al-Quran bukan berupa puisi atau prosa yang berirama sesuai dengan standarisasi penilaian Arab terhadap karya sastra pada waktu itu, akan tetapi banyak ayat yang terdapat dalam al-Quran memiliki persamaan rima dan sajak yang membuat ayat-ayat tersebut menjadi indah.

2. Al-Quran dihadirkan dengan menggunakan kata atau frasa yang maknanya dapat disesuaikan dengan berbagai konteks persoalan hidup, bial ada yang merubahnya maka akan terlihat janggal.

3. Setiap ayat yang digunakan saling menyempurnakan sehingga terlihat rapi.

4. Konsep atau ide yang disajikan oleh al-Quran memiliki unsur pengajaran yang berpengaruh bagi pembacanya.

5. Susunan al-Quran yang sempurna menjadikan al-Quran sebagai karya yang memiliki karya seni yang bernilai tinggi.

9 Bustam, Betty Mauli Rosa, Sejarah Sastra Arab dari Berbagai Perspektif, (Yogyakarta: deepublish publisher, 2015), 33-34. 
6. Gaya bahasa yang digunakan oleh al-Quran ringkas, tegas, dan efektif, lansung menyentuh kesadaran pembacanya.

7. Struktur teks al-Quran tidak seperti karya sastra pada umumnya.

Keindahan sastra al-Quran bukan 'kebetulan' diciptakan. Karena budaya bangsa Arab khususnya pada masa pra Islam, bangsa Arab mempunyai kesenangan dalam mendengarkan syair-syair indah. Oleh karena itu, al-Quran diturunkan dengan 'kekuatan' bahasa dan sastra bukan dengan 'kekuatan' filsafat yang menjadi 'kekuatannya' orang Yunani atau dengan 'kekuatan' pengobatan yang menjadi 'kekuatannya' orang China.

Dalam pandangan agama Islam, puisi mendapatkan tempat yang baik, khususnya puisi-puisi yang mengajarkan kepada kebenaran dan akhlak yang mulia. Hal ini tidak mengherankan, karena dalam ajaran Islam selalu ditekankan agar melakukan pekerjaan yang baik dan mencegah pekerjaan yang buruk. Mengenai dukungan Islam terhadap puisipuisi ini, Rasulullah SAW bersabda: inna min ash-shi'ri hikmāt 'sesungguhnya di antara puisi-puisi itu terdapat kata-kata hikmah'. Selain itu, Rasulullah juga sering memuji puisi Umaiyyah bin Abi Șalthi ath-Thasawafi, seorang penyair Jahili dari Ṭaif yang terkenal tidak suka minum khamar dan menyembah berhala. Bahkan Rasulullah pernah menghadiahkan burdahnya 'gamis' kepada Ka'ab bin Zuhair yang sedang membaca qașīdahnya yang berjudul Banāt Su'ad sehingga muncullah apa yang disebut dengan Qașīdah Burdah. ${ }^{10}$

\section{Al-Muhassināt dalam Bingkai Teori}

Muhassinat merupakan bagian dari ilmu Badi yang juga merupakan bagian dari Ilmu Balagah. Ilmu Badi’ pertama kali disusun oleh Abdullah bin al-Mu’taz al- 'Abbāsi (247-274 H) berupa keindahan-keindahan (muhassināt) dan dikumpulkan dalam sebuah buku yang bernama al-Badi'. Dalam kitab tersebut beliau berhasil mengumpulkan 18 belas muhassināt, baru kemudian Ja'far bin Qudāmah menambahkan 7 muhassināt dalam

${ }^{10}$ Males Sutiasumarga, Kesusatraan Arab: Asal Mula dan Perkembangannya, (Jakarta: Zikrul Hakim, 2000), 30. 
bukunya Naqd asy-Syi'r kemudian diikuti oleh ulama-ulama yang sehingga ditemukan banyak muhassināt.

Ilmu Badi digunakan untuk mengetahui aspek-aspek keindahan kalam (ungkapan bahasa Arab) baik berupa syair maupun prosa. Aspek keindahan ini dalam ilmu Badi dikenal dengan al- muhassināt atau sering juga disebut dengan al-Muhassināt alBadī'iyyah.

Al-Muhassināt terbagi dalam dua golongan, yaitu al-Muhassināt al-Ma'nawiyyah dan al-Muhassināt al-Lafziyyah. al-Muhassināt al-Ma'nawiyyah mengkaji keindahankeindahan yang kembali pada makna, sedangkan al-Muhassināt al-Lafdziyah mengkaji keindahan-keindahan yang kembali pada lafadz.

Al-Muhassināt al-Maknawiyah -secara teori- melihat aspek-aspek keindahan berikut ini:

1. Tiba $q^{11}$, ialah mengumpulkan dua kata dengan lawannya dalam kalam. Thibaq bisa saja berupa isim (nomina) kedua-duanya, fi'il (verba) kedua-duanya, harf (partikel) keduaduanya, ataupun antara $i \operatorname{sim}$ dan fi' $i l$. Țibāq terbagi lagi menjadi dua jenis, yaitu Ṭibāq Ijāb yang tidak berbeda positif dan negatifnya, dan Tibāq Salab yang terdapat perbedaan positif dan negatifnya.

2. Muqābalah, ialah mendatangkan dua makna atau lebih yang sesuai, kemudian didatangkan makna yang berlawanan dengan makna tersebut secara tertib. Muqābalah terbagi menjadi lima macam, yaitu muqābalah antara dua dengan dua, muqābalah antara tiga dengan tiga, muqābalah antara empat dengan empat, muqābalah antara lima dengan lima, dan muqābalah antara enam dengan enam.

3. Tauriyah, ialah menyebutkan satu kata yang memiliki dua makna. Makna yang pertama adalah makna qarīb (dekat),yakni makna yang jelas tetapi tidak dimaksud, makna yang kedua adalah makna $b a^{\prime} \bar{l} d$ (jauh),yakni makna yang tidak jelas dan merupakan makna yang dimaksud. Tauriyah terbagi menjadi empat macam, yaitu Tauriyah Mujarradah, yaitu tauriyah yang kosong dari sesuatu yang sesuai dengan kedua macam makna. Tauriyah Murashashah, yaitu tauriyah yang dibarengi dengan sesuatu yang sesuai

${ }^{11}$ Kata Tibāq sering dikategorikan dalam ranah keilmuan semantik (salah satu cabang keilmuan linguistik yang membahas tentang makna). Țibāq dalam isitiliah linguistik modern disebut dengan pertentangan makna atau antonimi. 
dengan makna dekatnya. Kemudian Tauriyah Muhayya'ah, yaitu tauriyah yang tidak pasti kecuali dengan kata sebelumnya atau sesudahnya, dan terakhir adalah Tauriyah Mubayyanah, yaitu tauriyah yang disebutkan makna lazimnya yang jauh karena sebelum itu makna yang dimaksud masih samar dan setelah disebutkan makna lazimnya maka jelaslah makna yang dimaksud.

4. Jam', ialah menghimpun dua hal atau lebih dalam satu hukum.

5. Tafrīq, ialah menetapkan perbedaan di antara dua perkara yang sejenis.

6. Taqsìm, ialah menyebutkan sesuatu yang berbilang,kemudian menyandarkan masingmasing bagian secara tertentu.

7. Murā'atu al-Naẓir, ialah mengumpulkan sesuatu yang sesuai,tetapi tidak dengan jalan yang berlawanan.

8. Husnu Ta'll̈l, suatu sifat yang diakui mempunyai sebab yang bukan sebenarnya,tetapi menimbulkan kelucuan.

9. Istikhdām, menyebutkan satu lafadz yang bermakna dua. Makna yang satu dinyatakan oleh lafadz itu sendiri, dan makna yang satu lagi dipahami dengan kembalinya ḍamir kepadanya. Demikian pula jika kedua makna itu,yang satu dipahami dengan sebab/dihubungi satu dhamir, sedang yang satu lagi dengan dhamir yang lain.

10. Muzawajah, menjodohkan dua makna dalam susun syarat dan jaza (jawab) dengan mengurutkan masing-masing dari keduanya satu makna yang diurutkan untuk yang lain.

11. Aț-Tay wa an-Nashr, ialah menyebutkan beberapa makna kemudian menuturkan makna yang populer bagi masing-masing tanpa menentukan, bersandar kepada upaya pendengar dalam membedakan makna bagi masing-masing makna tersebut dan mengembalikannya kepada yang semestinya. Aț-Tay wa an-Nashr terbagi dua yakni Nashr-nya menurut urutan țay dan nashr-nya tidak menurut urutan țay.

12. Al-Madzhab al-Kalām, ialah apabila seorang pembicara memberikan argumentasi yang pasti,yang tidak diterima oleh lawan bicara untuk menyatakan kebenaran pernyataannya,dengan pendahuluan-pendahuluan setelah diterima dapat menetapkan makna yang diharapkan. 
13. Ta'kīdul al-Madah bimā Yushbihu al-dzam, ialah memperkuat pujian dengan sesuatu yang menyerupai celaan.

14. Ta'kīdul al-Dzam bima Yushbihu al-Madah, memperkuat celaan dengan sesuatu yang menyerupai pujian

15. Tafrì, ialah menetapkan suatu perkara bagi sesuatu yang menjadi kaitannya sesudah menetapkan perkara tersebut bagi sesuatu yang lain,yang menjadi kaitannya.

16. Tajāhul al-Arif, kalimat-kalimat yang berisi pura-pura tidak tahu.

17. Tashābuh al-Ațrāf, terbagi menjadi dua yaitu pertama Tashābuh al-Ațrāf alMa'nawi (apabila antara awal kata dan akhir kata dalam suatu kalimat memiliki kesesuaian makna), kedua Tashābuh al-Ațrāf al-Lafdzy yaitu apabila lafadz yang terdapat pada akhir mișra'(setengah bait) pertama digunakan pada awal bait berikutnya, atau kata yang terdapat pada akhir bait digunakan digunakan pada awal bait berikutnya.

Sedangkan al-Muhassināt al-Lafzhiyah-secara teori- memperhatikan keindahankeindahan lafadz seperti berikut:

1. Jinās, yaitu kemiripan penggunaan dua lafadz yang berbeda artinya.Terbagi menjadi dua, yaitu Jinās Tam ${ }^{12}$ dan Jinās Gair Tam.

2. Saj', ialah cocoknya dua fașilah dalam nathar dalam satu huruf. Ada tiga jenis, yaitu pertama Saj' Muțarraf apabila kedua lafadznya bersamaan hurufnya akan tetapi berbeda wazannya, Kedua Saja' Murașșa yaitu saja yang lafad-lafadz dari rangkaiannya,seluruh atau sebagian besar sama nadzam dan huruf akhirnya. Ketiga Saja’ Mutawazi yaitu saja' yang sama wazan dan huruf akhirnya pada kata-kata akhir saja',sedangkan kata-kata sebelumnya tidak.

12 Jinas Tam adalah terjadi jika ada dua lafadz di dalamnya terdapat kesesuaian dalam empat hal, yaitu macam-macamnya, hurufnya, syakalnya, dan tartibnya. Sedangkan Jinas Gahir Tam adanya perbedaan salah satu unsur dari unsur-unsurnya. Perbedaan tersebut mungkin terjadi pada macam-macamnya, hurufnya, syakalnya, ataupun pada tartibnya atau susunannya. Dalam konteks pelafalannya, jinas juga bisa dibagi menjadi beberapa jenis, (1) Jinās Mumatsil, (2) Jinās Mustaufi, (3) Jinas Ishtiqāq, (4) Jinās al-Mushābah bi al-Ishtiqāq, (5) Jinās al-Mutashābih, (6) Jinās al-Murakkab, (7) Jinās al-Muḍāri', (8) Jinās al-Lāhiq, (9) Jinās an-Nāqiș, (10) Jinās al-Muharraf, (11) Jinās al-Qalb, (12) Jinās al-Muḍ̄āf, (13) Jinās al-Muzdawij, (14) Jinās at-Tashīf, (15) Jināsāt Thulāthoyah, (16) Jinās Thunāiyah antara kalimat-kalimat thusatha. Jinās ini bisa terjadi antara isim dengan isim, fi'il dengan fi' 'il, isim dengan fi'il, dzaharaf dengan isim, isim dengan huruf, ataupun bisa juga berupa penambahan huruf seperti penambahan di awal kata, penambahan di tengah kata ataupun penambahan di akhir kata. Lihat Mardjoko Idris, Ilmu Balaghah..., 9-56. 
3. Iqtibās, yaitu penyusunan prosa atau puisi yang mengandung dari al-Quran atau alHadits tanpa petunjuk bahwa itu dari al-Quran atau al-Hadits.

4. Raddu al-'Ajz 'ala al-Șadr, ialah kesamaan dua kata antara awal dan akhir kalimat

5. Muwāzanah, yaitu persamaan dua fașilah dalam wazannya tetapi berbeda huruf akhirnya.

\section{Abstraksi Ayat Kewajiban Berjuang di Jalan Allah}

1. Redaksi Ayat

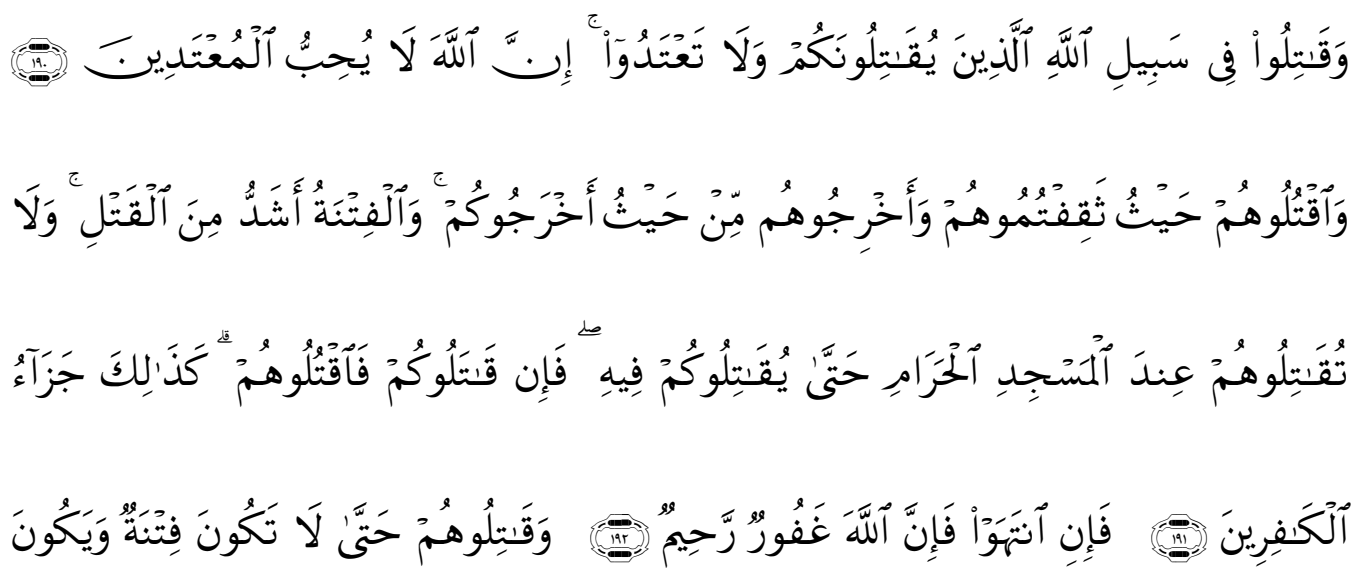

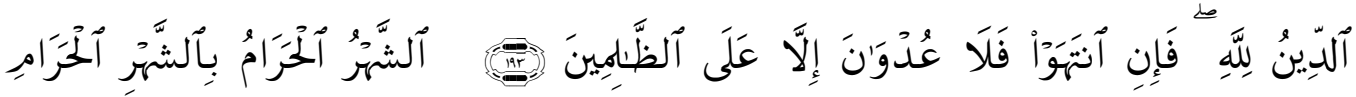

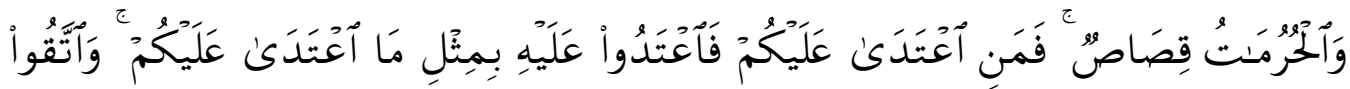

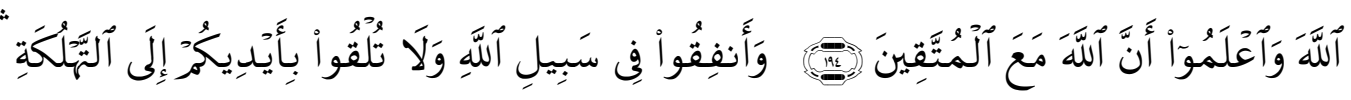

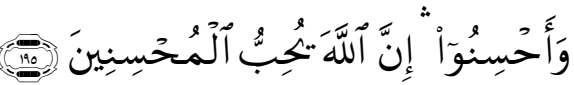

Artinya 
190. Dan perangilah di jalan Allah orang-orang yang memerangi kamu, (tetapi) janganlah kamu melampaui batas, karena Sesungguhnya Allah tidak menyukai orang-orang yang melampaui batas.

191. Dan bunuhlah mereka di mana saja kamu jumpai mereka, dan usirlah mereka dari tempat mereka telah mengusir kamu (Mekah); dan fitnah itu lebih besar bahayanya dari pembunuhan, dan janganlah kamu memerangi mereka di Masjidil haram, kecuali jika mereka memerangi kamu di tempat itu. jika mereka memerangi kamu (di tempat itu), Maka bunuhlah mereka. Demikanlah Balasan bagi orang-orang kafir.

192. Kemudian jika mereka berhenti (dari memusuhi kamu), Maka Sesungguhnya Allah Maha Pengampun lagi Maha Penyayang.

193. Dan perangilah mereka itu, sehingga tidak ada fitnah lagi dan (sehingga) ketaatan itu hanya semata-mata untuk Allah. jika mereka berhenti (dari memusuhi kamu), Maka tidak ada permusuhan (lagi), kecuali terhadap orang-orang yang zalim.

194. Bulan Haram dengan bulan haram], dan pada sesuatu yang patut dihormati, Berlaku hukum qishaash. oleh sebab itu Barangsiapa yang menyerang kamu, Maka seranglah ia, seimbang dengan serangannya terhadapmu. bertakwalah kepada Allah dan ketahuilah, bahwa Allah beserta orang-orang yang bertakwa.

195. Dan belanjakanlah (harta bendamu) di jalan Allah, dan janganlah kamu menjatuhkan dirimu sendiri ke dalam kebinasaan, dan berbuat baiklah, karena Sesungguhnya Allah menyukai orang-orang yang berbuat baik. ${ }^{13}$

2. Abstraksi Ayat

Ayat ini merupakan perintah dari Allah SWT kepada orang-orang yang beriman kepada-Nya untuk berperang demi menegakkan Kalima Allah dan memuliakan agamaNya. Perperangan ini ditujukan kepada orang-orang kafir. Dalam berperang Allah melarang melanggar norma-norma kemanusiaan seperti pembunuhan terhadap anakanak dan lainnya.

Perintah untuk berperang ini tidak terbatas pada tempat, walaupun berada di kota Makkah. Karena perbuatan musuh yang mengintimidasi, menyebarkan fitnah, menyita harta benda merupakan hal yang keji dan lebih kejam dari pembunuhan. Serta Allah melarang untuk berperang di Masjidil Haram terkecuali diserang terlebih dahulu.

Dalam ayat ini, Allah menjelaskan tujuan perperangan yaitu agar tidak terdapat fitnah, musuh tidak mengintimidasi dan pada akhirnya musuh menyembah kepada Allah SWT. Kemudian di ayat terakhir Allah memerintahkan manusia untuk berjihad dengan harta benda, sesudah sebelumnya memerintahkan dengan jihad jiwa dan raga.

\section{Kandungan Hukum}

Menurut Ali ash-Shabūni, ayat ini memiliki beberapa pokok hukum yang dapat dirumuskan, yaitu:

\footnotetext{
${ }^{13}$ QS. Al-Baqarah 190-195.
} 
a. Bilakah kewajiban berjihad ditetapkan atas kaum muslimin?

b. Apakah ayat yang pertama merupakan perintah (syariat) untuk berperang?

c. Apakah dibolehkan berperang di Masjidil Haram?

d. Siapakah yang dimaksud dengan musuh ('udwaan)?

Dalam hal ini, penulis tidak membahas secara mendalam kandungan hukum yang terdapat dalam ayat ini, akan tetapi dari pokok-pokok rumusan di atas as-Shabuni berkesimpulan bahwa:

e. Perperangan harus bertujuan untuk menegakkan Kalimat Allah dan memuliakan agama-Nya,

f. Allah swt tidak menyukai pelanggaran, kezhaliman, dan kesewenang-wenangan, apapun asal-usulnya,

g. Mengintimidasi orang-orang yang beriman dengan jalan penindasan, dan penganiayaan sama jahatnya dengan pembunuhan,

h. Allah swt melarang memerangi perempuan, orang-orang yang lemah, dan anak-anak,

i. Jihad dilakukan untuk menolak gangguan kaum musyrikin, menghilangkan fitnah dan memberikan rasa aman dalam berdakwah,

j. Jihad tidak hanya dengan berperang tapi bisa dengan berinfak atau berjihad dengan harta.14

\section{Kandungan Muhassināt pada Ayat Hukum}

1. Al-Muhassināt al-Maknawiyah

a. Tibāq

Ṭibāq juga sering disebut dengan ațad, terdapat pada ayat 191. Pada ayat tersebut, kata berkumpul dengan kata yang memiliki makna yang berlawanan. Kata mennggunakan sigah fi'il amar sedangkan kata menggunakan sigah fi'il nahy. Kesimpulannya, kedua kata tersebut, kedua-duanya

\footnotetext{
${ }^{14}$ Muhammad Ali ash-Shabuni, Rawai'ul Bayan Tafsir Ayatil Ahkam Minal Quran Juz 1, terj. Saleh Mahfoed dengan judul Tafsir Ayat-Ayat Hukum dalam al-Quran (Damsyik: Maktabah Al-Ghazali, 1971), 391-419.
} 
menggunakan $f i^{\prime} i l$ dengan $f i$ 'il dalam konsep țibāq disebut dengan țibāq salab yang dimana kata berupa manfi (positif) dan kata berupa muthbat (negatif).

b. Tauriyah

Kata أيدٍ pada ayat 195 memiliki dua makna, yaitu makna dekat (al-ma'na alqarīb) dan makna jauh (al-ma'na al-ba's̄d). Makna dekatnya adalah tangan biasa seperti yang ada pada anatomi tubuh manusia sedangkan makna jauhnya adalah harga diri. Makna yang dimaksud dalam ayat ini adalah makna jauhnya yaitu jiwa dan raga. Kata أيدٍ pada ayat ini termasuk dalam jenis tauriyah mujarradah karena tauriyah kosong dari sesuai dengan kedua macam makna.

c. Jam

al-Muhassināt Jam' terdapat pada ayat 194, yaitu terdapat pengumpulan dua hal dalam satu hukum. Dua hal tersebut adalah الثهر الحرام dan yang terkumpul dalam satu hukum yaitu pembolehan hukum qișaș.

d. Taqsim

Penyebutan sesuatu yang berbilang atau taqsìm dapat ditemukan pada ayat 193 yaitu ada dua tujuan memerangi orang-orang kafir. Tujuan membunuh orang kafir pada ayat di atas adalah diungkapkan dengan kata 'supaya tidak terjadi lagi fitnah' dan يكون الدين اله 'ketaatan hanya kerana Allah”.

\section{Al-Muhassināt al-Lafdziyah}

a. Jinās

Keindahan lafadz yang pertama pada ayat hukum ini bisa ditemukan pada ayat 194 yaitu al-muhassināt al-fadziyah jenis jinās tam. Kemiripan lafadz yang digunakan tidak hanya pada huruf, akan tetapi juga pada syakal dan jumlah hurufnya. Ada dua kalimat yang diulang dua kali dalam ayat ini, pertama kata dan kedua

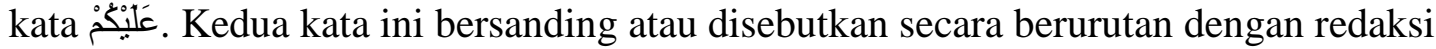
. إعنَََي عَلْيْْْْ Namun yang mencukupi syarat al-muhassināt kategori jinās tam hanya pada kata karena kata pada awal awal kata memiliki makna yang berbeda dengan kata yang sama pada fașillah (akhir kata). Kata pada awal kata memiliki arti 'orang yang menyerang' karena di awali oleh kata sebelumnya, sedangkan kata pada akhir kalimat memiliki arti 'besarnya serangan' karena sebelum kata tersebut di awali dengan kata yang menunjukkan 'seberapa besar'. 


\section{b. Radd al-A'jz 'ala al-Șadr}

Radd al-A'jz 'ala al-Șadr pada ayat-ayat jihad terdapat di beberapa tempat. Pertama pada ayat 190 yaitu adanya kesamaan kata (kalimah) di awal dan diulangi lagi dengan dengan kata يقاتلونكم. Kedua, pada ayat yang sama terdapat pengulangan kata dan di ulangi di akhir ayat dengan redaksi المعتدين.

Pada ayat 193, ditemukan radd al-a'jz 'ala al-șadr pada kalimat . Kata

digunakan dengan shighah yang mirip pada akhir kalimat yaitu

Selain itu, pada ayat 194 juga terdapat radd al-a’jz 'ala al-șadr, yaitu adanya kesamaan penggunaan kata 'bertakwalah' dalam bentuk (sigah) fi'il amar pada awal kalimat dengan kata المتقين 'orang-orang yang bertakwa' di akhir ayat.

Selain beberapa ayat di atas, ayat terakhir yaitu ayat 195 juga mengandung al-muhassināt al-badī'iyah yaitu radd al-a'jz 'ala al-al-șadr. Dalam ayat ini ada kesamaan penggunaan kata kerja perintah (fi'il amar) pada kata pada awal kalimat dengan kalimat المحسنين.

\section{Simpulan}

Bahasa al-Quran merupakan senjata (baca: 'Ijāz) yang ampuh untuk menandingi kekuatan bahasa dan sastra Arab yang sudah maju pada zaman Islam bahkan pra Islam. Kemukjizatannya dapat dirasakan dan didengar baik secara makna maupun lafadz. Keindahan pada makna dapat dirasakan sedangkan keindahan lafadz dapat didengar. Keindahan nada dalam al-Quran tidak hanya pada ayat-ayat yang bertemakan nasehat akan tetapi juga pada ayat-ayat hukum yang mempunyai karakter tanpa emosi, datar, dan kering serta memprioritaskan mono semantik untuk mengurangi banyaknya penafsiran dan perdebatan hukum apalagi ayat-ayat yang bertemakan kewajiban untuk berjihad di jalan Allah yang berkarakter keras dan mengerikan.

Uraian pada bagian pembahasan membuktikan, setidaknya ada 9 (sembilan) muhassināt ditemukan pada ayat-ayat kewajiban berjihad di jalan Allah. Keindahankeindahan tersebut tidak hanya pada makna (al-muhassināt al-ma'nawiyah) akan tetapi juga terdapat pada lafadz (al-muhassināt al-lafdziyah). 
Al-Muhassināt al-Ma'nawiyah dalam ayat-ayat ini ditemukan 4 (empat) jenis, yaitu Ṭibāq, Tauriyah, Jam' dan Taqsìm. Sedangkan dalam al-Muhassināt al-Lafdziyah ditemukan dua jenis keindahan, yaitu Jinās dan Radd al-A'jz 'ala al-Ṣadr. Hal ini menunjukkan ayat-ayat tentang kewajiban berjihad di jalan Allah memiliki kedua jenis muhassināt yang terdapat dalam ilmu Badi'.

Keindahan-keindahan yang bisa diketengahkan selain keindahan-keindahan yang terdapat dalam ilmu Badi' adalah munculnya ayat tentang jenis jihad di jalan Allah yang lain setelah jihad di jalan Allah dengan cara perperangan. Hal ini membuktikan bahwa ayat ini tidak berbicara tentang hukum berjihad dengan penuh emosi akan tetapi disusun dengan nada yang indah dan tensi diredam dengan muncul cara lain dalam berjihad dijalan Allah yaitu dengan berzakat pada akhir ayat.

Akhirnya,tulisan ini membutuhkan tulisan-tulisan atau penelitian lanjutan yang khusus membahas dan mengungkapkan keindahan-keindahan dengan tema yang lain dalam al-Quran. Selain itu, ayat-ayat tentang kewajiban berjihad ini juga memerlukan peninjauan dan analisis yang lebih komplek menggunakan pisau bedah disiplin ilmu lain. Hal ini penting, supaya pembacaan ayat-ayat ini bisa lengkap atau komplek.

\section{Daftar Pustaka}

Bustam, Betty Mauli Rosa, Sejarah Sastra Arab dari Berbagai Perspektif, (Yogyakarta: deepublish publisher, 2015).

Goys Keraf, Diksi dan Gaya Bahasa, (Jakarta: Gramedia Pustaka Utama, 2007).

Idris, Mardjoko, Semantik al-Quran: Pertentangan dan Perbedaan Makna, (Yogyakarta: Teras, 2008).

Idris, Mardjoko, Ilmu Balaghah: Kajian Uslum Jinas dan Iqtibas, (Yogyakarta, Teras, 2007).

Hifni Bek Dayyab dkk, Qowā'idu'l-lughati al-Arabiyyah, terj. Chotibul Umam dkk, (Jakarta: Darul Ulum Press, 2004).

Kholis Setiawan, al-Quran Kitab Sastra Terbesar (Yogyakarta: Elsaq Press, 2006).

Majdi Wahbah dan Kamil Muhandits, Mu'jam al-MuȘtalahāt al- 'Arabiyyah fì al-Lugati wa al-'Alām, (Beirut: Maktabah Lubnan, 1984). 
Males Sutiasumarga, Kesusatraan Arab: Asal Mula dan Perkembangannya, (Jakarta: Zikrul Hakim, 2000).

Mustafa Amin Ali al-Jarīm, al-Balāgah al-Waḍ̄hhah, (Kairo: Dār al-Ma’ārif, 1951).

Rudy Hariyono dan Andrew MC. Carthy, ABD Plus English Grammar, (Surabaya: Gitamedia Press, 2008).

Sayyid Muhammad al-Maliki, Keistimewaan-keistimewaan al-Quran, terj. Nur Fauzin, (Yogyakarta: Mitra Pustaka, t.t).

aṢ-Șabūni, Muhammad Ali, Rawāì'ul Bayān Tafsīr Ayatil Ahkām Minal Quran, Juz 1, terj. Saleh Mahfoed dengan judul Tafsir Ayat-Ayat Hukum dalam al-Quran, (Damsyik: Maktabah Al-Ghazali, 1971).

, Muhammad Ali, Studi Ilmu al-Quran. Terj., (Bandung: Pustaka Setia, 1998). 